\title{
Survey of Synthetic Routes towards Phosphorus Substituted Porphyrins
}

\author{
Alla G. Bessmertnykh-Lemeune, ${ }^{a}$ Christine Stern, ${ }^{a}$ Yulia G. Gorbunova, ${ }^{\text {b,c }}$ \\ Aslan Yu. Tsivadze, ${ }^{\mathrm{b}, \mathrm{c}}$ and Roger Guilard ${ }^{\mathrm{a} @}$ \\ Dedicated to the Corresponding member of Russian Academy of Sciences Prof. Oscar Koifman \\ on the occasion of his Anniversary \\ a'Institut de Chimie Moléculaire de l'Université de Bourgogne (ICMUB), 21078 Dijon, France \\ ${ }^{\mathrm{b}}$ A.N. Frumkin Institute of Physical Chemistry and Electrochemistry, Russian Academy of Sciences, 119071 Moscow, Russia \\ 'N.S. Kurnakov Institute of General and Inorganic Chemistry, Russian Academy of Sciences, 119991 Moscow, Russia \\ ${ }^{\circledR}$ Corresponding author E-mail: Roger.Guilard@u-bourgogne.fr
}

This brief review summarizes the synthetic approaches towards porphyrins bearing a C-P bond at the periphery of the macrocycle. In the first section we detail the non catalytic pathways for the synthesis of phosphorus substituted porphyrins using different phosphonate precursors or by derivatization of a pre-existing porphyrin. In the second section we demonstrate that palladium-or copper-catalyzed phosphorylation of halogen substituted porphyrins is an efficient method to prepare meso- and $\beta$-phosphoryl substituted porphyrins.

Keywords: Phosphoryl porphyrins, transition metal catalized cross-coupling, formation of C-P bonds, pyrrole, phosphorus.

\section{Синтетические подходы к получению фосфор-замещенных порфиринов}

\author{
А. Г. Бессмертных-Аемен, ${ }^{a}$ К. Штерн, ${ }^{a}$ Ю. Г. Горбунова, ${ }^{\mathrm{b}, \mathrm{c}}$ \\ А. Ю. Цивалзе,
}

Посвящается Член-корреспонденту РАН, профессору О. И. Койфмману по случаю его юбилея

\begin{abstract}
а Институт молекулярной химии Университета Бургундии, 21078 Дижон, Франщия
${ }^{\mathrm{b}}$ ФБУН Институт физической химии и электрохимии им. А.Н. Фрумкина РАН, 119071 Москва, Россия

${ }^{ }$ФГБУН Институт общей и неорганической химии им. Н.С. Курнакова РАН, 119991 Москва, Россия

@E-mail: Roger.Guilard@u-bourgogne.fr
\end{abstract}

В кратком обзоре обсуждаются методы синтеза порфиринов, содержаших связь С-P на периферии макро-цикла. Первая часть обзора содержит сведения о некаталитических подходах к получению фосфорзаме-щенных порфиринов с использованием различных фосфонатных прекурсоров, в том числе исходя из предварительно синтезированных замещзенных порфиринов. Вторая часть обзора посвящена обсуждению эффективных синтетических подходов к получению мезо- и $\beta$-фосфорилпорфиринов из галоген-замещенных производных порфиринов и диалкилфосфитов в присутствии комплексов переходных металлов.

Ключевые слова: Фосфорилпорфирины, катализируемые переходными металлами реакции кросс-сочетания, образование связи С-Р, пиррол, фосфор. 


\section{Introduction}

Many papers and reviews have been dedicated to the synthesis and substitution of the porphyrin core to obtain macrocyclic derivatives for a specific property and a particular application, ${ }^{[1-5]}$ but only few papers are related to studies of phosphoryl porphyrins. However, the presence of a phosphonate group at the periphery of the macrocycle is essential to graft a dye on a semiconductor and more generally such type of receptors can be used as assembling ligand. Some studies investigated the effects of the anchoring group nature to improve the light collection efficiency of DSSCs or others and mainly to compare the efficiency of carboxylate versus phosphonate moieties as grafting groups. ${ }^{[6-10]}$ More generally phosphoryl porphyrins can be used to fabricate photonic materials, for studies of biological systems or to elaborate molecular solids displaying sensor and catalytic properties.

Only a few syntheses of porphyrins bearing a C-P bond at the periphery of the macrocycle were described due to the limited availability of an appropriate synthetic method. In this review we only detail the synthesis of derivatives possessing a pentavalent phosphorus component. Two synthetic approaches can be employed to prepare phosphoryl porphyrins - non catalytic pathway or transition metalmediated cross-coupling reactions.

\section{Non Catalytic Pathways for C-P Bond Formation at Porphyrin Periphery}

\section{Reactions Using Susbtitution of Porphyrinic Macrocycles}

In a pioneering work Smith and coworkers described in 1977 the introduction of a meso-triphenylphosphonium substituent at the porphyrin periphery via a radical cation formation. ${ }^{[11,12]}$ Treatment of $\mathrm{Zn}(\mathrm{II})$-octaethylporphyrin with $\operatorname{tris}(p$-bromophenyl)ammoniumylhexachloroantimonate generates the $\pi$ cation radical of the porphyrin which was reacted with triphenylphosphine. A demetallation reaction gave the meso-triphenylphosphonium octaethylporphyrin chloride 1, but the UV-visible absorption spectroscopy indicated that there was a significant resonance contribution from the porphyrin cation. The relative stability of the phosphonium salt limited the extension of the Wittig reaction into porphyrin chemistry. This was attributed to the highly stabilized ylide $\mathbf{2}$ and the steric repulsion of the reactants.
The structure of $\mathbf{2}$ possesses a variant of the theoretically interesting isoporphyrin chromophore (Scheme 1).

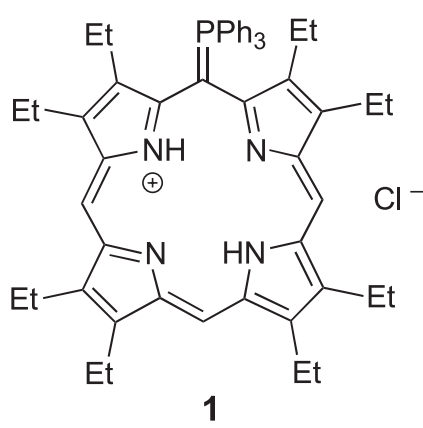<smiles>CCC1=C(CC)C(=P)C(C(=P)c2ccccc2)=N1</smiles>

Scheme 1.

( $\beta$-Porphyrinyl)phosphonium salt $\mathbf{3}$ generated from $\mathrm{Zn}(\mathrm{II})$-tetraphenylporphyrin was first reported by Shine et al. (Scheme 2). ${ }^{[13,14]}$

The same phosphonium salt $\mathbf{3}$ was synthesized by Giraudeau et al. from the corresponding electrochemically generated cation radical. ${ }^{[15]}$ In parallel the analogous $\beta$-phosphonium salt was obtained from a chemically generated $\mathrm{Fe}$ (III)-tetraphenylporphyrin cation radical after treatment with $\mathrm{PPh}_{3} \cdot{ }^{[16]}$

Through the electrochemical procedure, Giraudeau et al. have prepared di- and triporphyrins linked by phosphonium bridges. ${ }^{[17-19]}$ The electrochemically generated $\mathrm{Zn}$ (II)tetraphenylporphyrin cation radical was treated with di- and triphosphines to yield porphyrin oligomers, as an example the dimer 4 (Scheme 3). ${ }^{[17]}$

The free base tris(mesityl) porphyrin $\mathbf{6 a}$ has been also obtained by treating the bromoporphyrin $\mathbf{5}$ with trimethyl phosphite according Arbuzov reaction in $79 \%$ yield (Scheme 4). ${ }^{[20]}$

One complementary route allowed the preparation of di-tert-butyl porphyrinic phenylphosphonates by acting di-tert-butyl phosphite with an iodo-phenyl substituted porphyrin with di-tert-butyl phosphite in a Pd-mediated coupling process. ${ }^{[21]}$

In 2004 Uemura and coworkers prepared the porphyrinthioyl hybrid ligand by treatment of 3 '-(diphenylphosphinothioyl)biphenyl-2-carbaldehyde 7 with dipyrromethane in the presence of trifluoroacetic acid followed by oxidation with $p$-chloranil (Scheme 5). ${ }^{[22]} \mathrm{A}$ mixture of syn-and anti-isomers was formed but only the $s y n$-isomer $\mathbf{8}$ was isolated as a pure derivative in $21 \%$ yield.<smiles>CC(C)[C@H](C)[C@H](C)c1ccccc1</smiles>

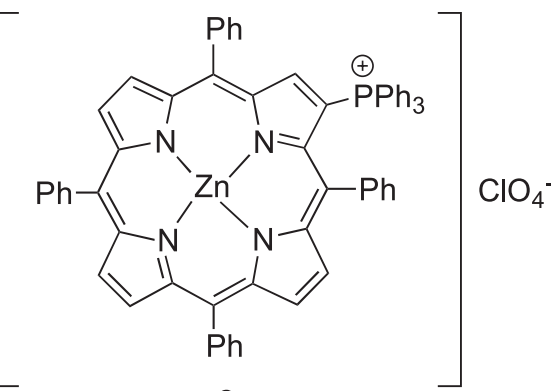


<smiles></smiles>
2,6-lutidine

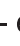

$72 \%$

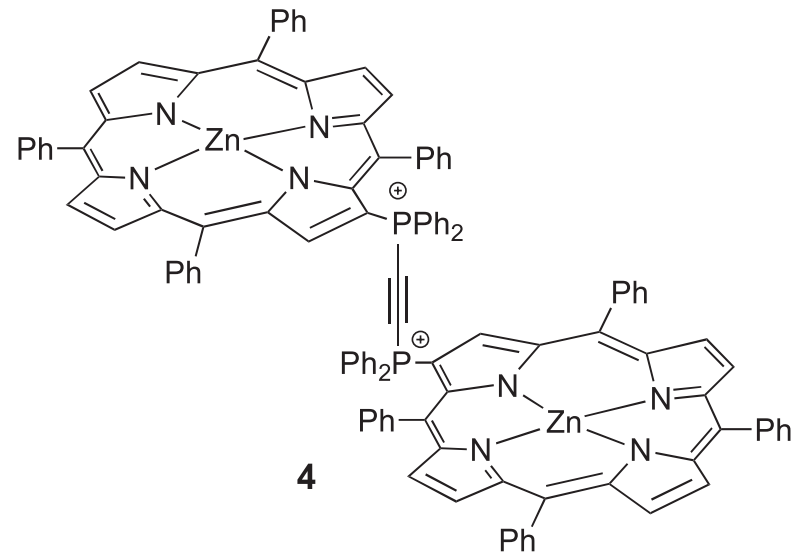

Scheme 3.
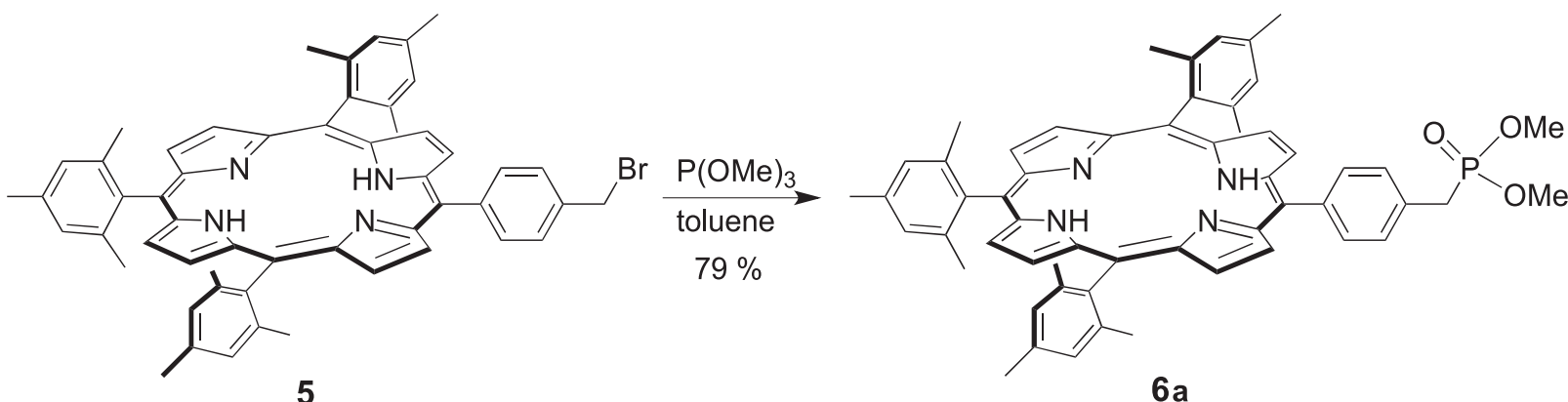

Scheme 4.

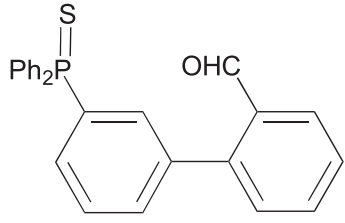

1) dipyrromethane,

TFA, $\mathrm{CH}_{2} \mathrm{Cl}_{2}$

2) p-chloranil, $\mathrm{CH}_{2} \mathrm{Cl}_{2}$

7

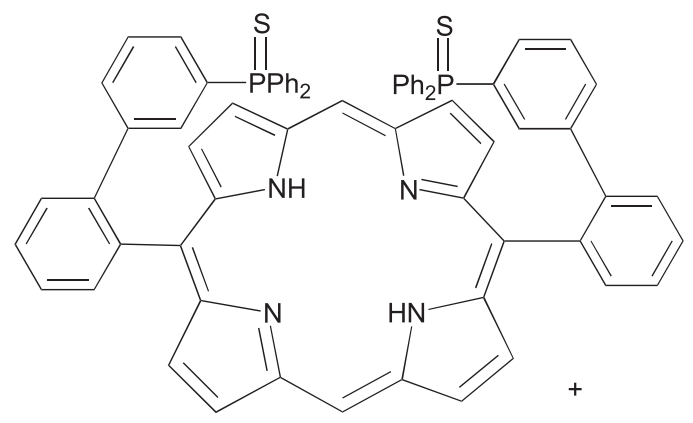

syn-8

$21 \%$

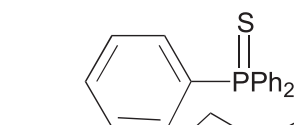

$\mathrm{Zn}(\mathrm{OAc})_{2}$

syn-8 $\stackrel{\mathrm{MeOH}, \mathrm{CHCl}_{3}}{\longrightarrow}$

$98 \%$

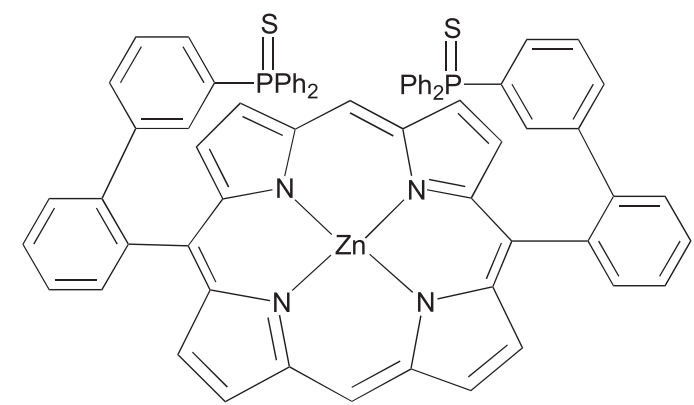

anti-8

not isolated

syn-9

\section{Scheme 5.}


The corresponding syn-zinc porphyrin 9 was obtained by metallation with $\mathrm{Zn}(\mathrm{OAc})_{2}$ in $98 \%$ isolated yield.

Two main synthetic approaches can be employed to prepare porphyrins bearing phosphonate units. Indeed, the phosphonate moiety can be introduced either into precursors of the porphyrin or by derivatization of a pre-existing porphyrin scaffold. The first described syntheses were mainly based on the first strategy while the second one has been successfully developed more recently. These two strategies are detailed below.

\section{Synthesis of Porphyrins Using Phosphonate}

\section{Precursors}

The first preparation of manganese porphyrins tetrafunctionalized with phosphonic acid has been reported by Bujoli and coworkers in 1995. ${ }^{[23]}$ This synthesis based on the classical condensation of pyrrole with the corresponding aldehyde under Adler conditions has been then described by Odobel and coworkers to form porphyrin (Scheme 6). ${ }^{[24]}$

The meso-tetraarylporphyrins $\mathbf{1 0}$ have been prepared by condensation of pyrrole with the para- and meta-phosphoryl substituted benzaldehydes, while the trans-porphyrin $\mathrm{A}_{2} \mathrm{~B}_{2} \mathbf{1 1}$ was obtained through the MacDonald [2+2] condensation of 5-phenyl-dipyrromethane with the functionalized benzaldehyde (Scheme 7) ${ }^{[24]}$ It has to be noted that the functionalized benzaldehydes were prepared by Hirao's reaction. Protection of the aldehyde group is needed to obtain the target precursors under these conditions in good yields.

Over the same period Lindsey and coworkers synthesized phosphonic acids attached to porphyrins by

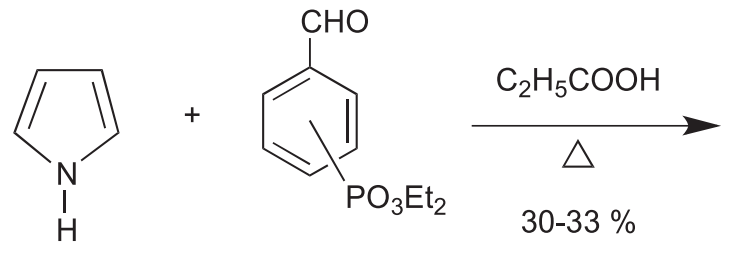

Scheme 6.<smiles>CCOc1ccc(C=O)cc1</smiles>

condensation reactions of pyrrole with the phosphonic ester derived reagent and mesitaldehyde (Scheme 8). ${ }^{[20]}$

The precursor phosphonate aldehyde $\mathbf{1 2}$ was obtained in three steps from $\alpha$-bromo- $p$-toluic acid. Arbuzov reaction of this acid with diethylphosphite was used to introduce the phosphorus substituent.

The cocondensation of this aldehyde, mesitaldehyde and pyrrole at high concentration using $\mathrm{BF}_{3} \cdot \mathrm{O}(\mathrm{Et})_{2}$ /ethanol co-catalysis gave a mixture of porphyrins from which the $\mathrm{A}_{3} \mathrm{~B}$ porphyrin $\mathbf{6 b}$ was obtained in $9.4 \%$ yield. The zinc complex 13 obtained in $94 \%$ yield was treated with TMS-Br and TEA in refluxing $\mathrm{CHCl}_{3}$ to induce cleavage of the ethyl protecting groups giving porphyrin benzylphosphonic acid $\mathbf{1 4}$ in $78 \%$ yield.

Lindsey and coworkers also reported univocal synthesis of a porphyrin-phosphonic acid bearing $p$-tolyl groups at three meso-positions by condensation of a phosphonate substituted dipyrromethane $\mathbf{1 5}$ and a dipyrromethane-dicarbinol 16 (Scheme 9). ${ }^{[20]}$ The condensation of $\mathbf{1 5}$ and $\mathbf{1 6}$ using $\mathrm{InCl}_{3}$ as catalyst led to a free base porphyrin which after metallation with $\mathrm{Zn}(\mathrm{OAc})_{2} \cdot 2 \mathrm{H}_{2} \mathrm{O}$ afforded the $\mathrm{Zn}(\mathrm{II})$ complex 17.

\section{Catalytic Pathways for Synthesis of Phosphoryl Porphyrins}

In 2006 Arnold and coworkers described a new class of porphyrins with one and two diphenylphosphine oxide substituents in meso-position (Scheme 10). ${ }^{[25,26]}$

Attempts to obtain meso-porphyrinyl phosphine by the method of Stille led to the corresponding phosphine oxide

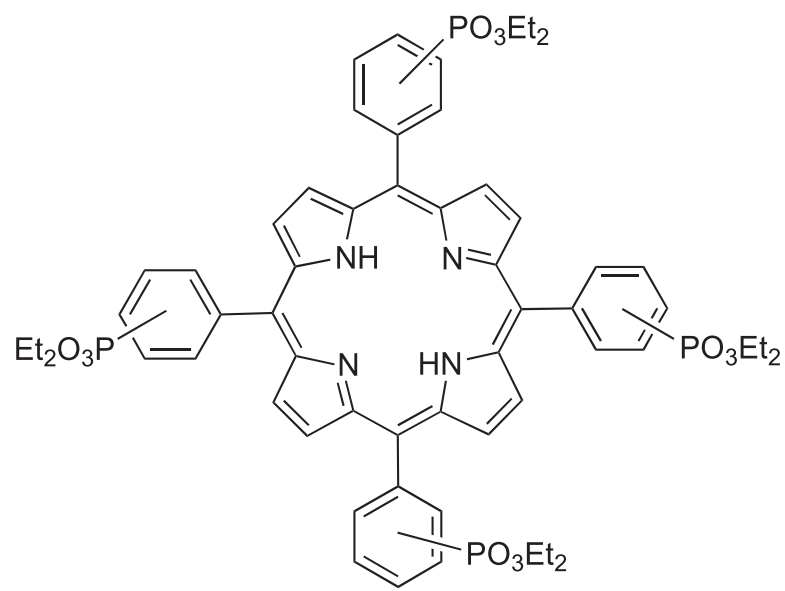

10 
<smiles>CCOP(=O)(Cc1ccc(C=O)cc1)OCC</smiles>

1) mesitaldehyde, pyrrole, $\mathrm{BF}_{3} \cdot \mathrm{OEt}_{2} /$ ethanol, $\mathrm{CHCl}_{3}$ 2) $D D Q$

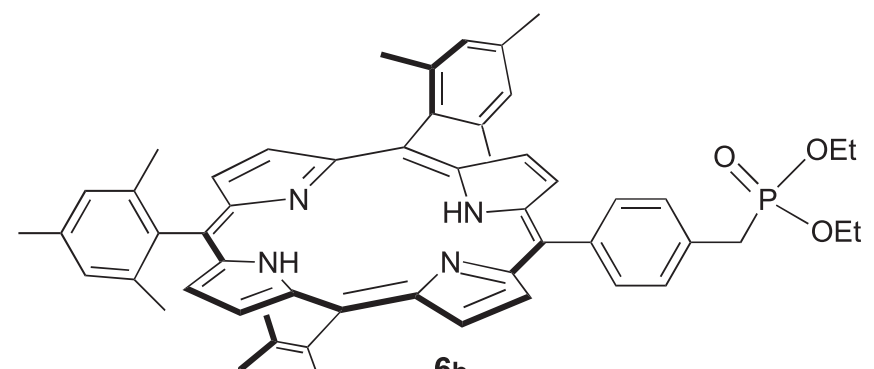

12

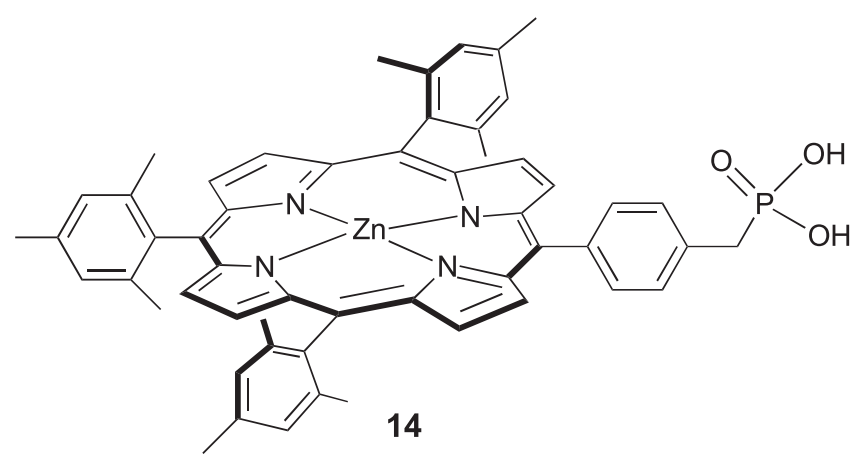

$6 b$

$\mathrm{Zn}(\mathrm{OAc})_{2} \cdot 2 \mathrm{H}_{2} \mathrm{O}$ $\mathrm{CHCl}_{3} / \mathrm{MeOH}$

$94 \%$

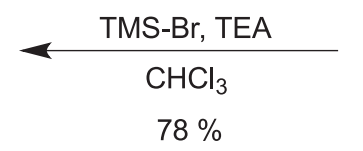

13

Scheme 8.

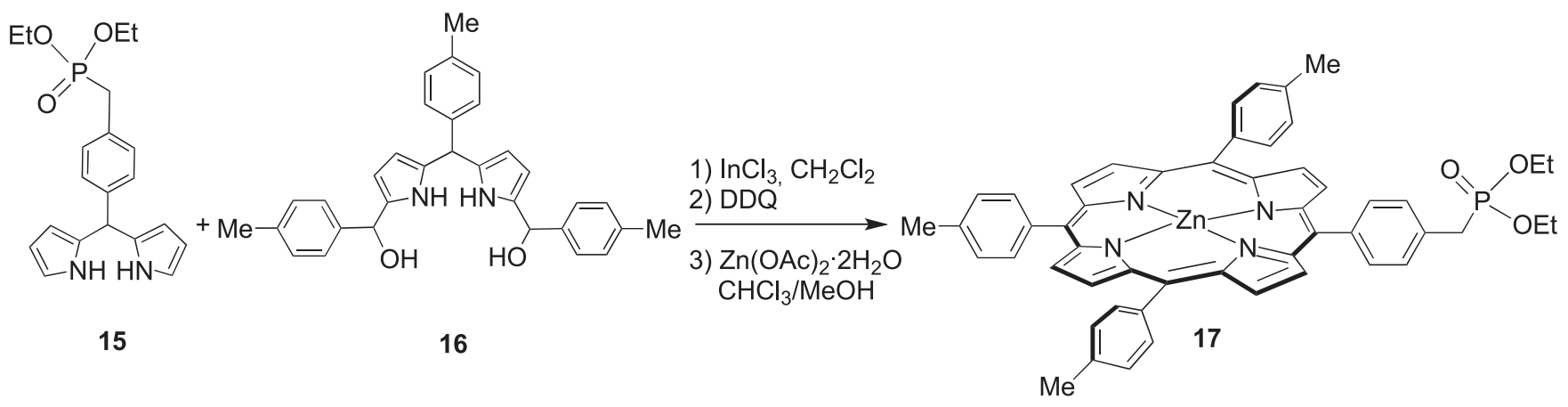

Scheme 9.

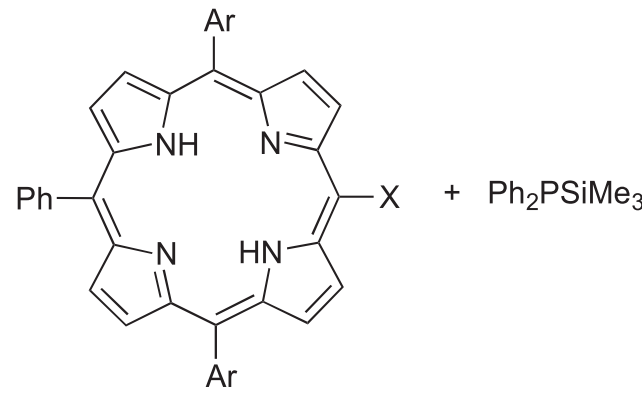

18a $(X=B r) ; 18 b(X=I)$

Ar: 3,5-bis(t-butyl)phenyl
$\left(\mathrm{CH}_{3} \mathrm{CN}\right)_{2} \mathrm{PdCl}_{2}$ cat.

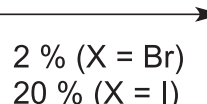
$20 \%(X=I)$

Scheme 10.

19 because these phosphines tend to oxidize very readily in the presence of porphyrins to the corresponding oxides. The target product was obtained in very low yields of $2 \%$ when the bromoporphyrin 18a was the porphyrinic precursor. A higher yield of $20 \%$ was obtained starting from iodoporphyrin $\mathbf{1 8 b}$ which is more reactive.
In another experiments the palladium complex $\mathbf{2 0}$ which is the intermediate compound in the suggested palladiumcatalyzed reaction was used as starting material. ${ }^{[26]}$ This intermediate $\mathbf{2 0}$ is readily available from a stoichiometric oxidative addition of the corresponding bromoporphyrin to $\left[\mathrm{Pd}_{2} \mathrm{dba}_{3}\right]$ in the presence of dppe ligand. The reaction of $\mathbf{2 0}$ 
with $\mathrm{Ph}_{2} \mathrm{P}(\mathrm{O}) \mathrm{H}$ and $\mathrm{Cs}_{2} \mathrm{CO}_{3}$ as a base gave the phosphine oxide 21 in excellent yield (85\%) (Scheme 11). ${ }^{[26]}$

Corresponding nickel and zinc porphyrins substituted in one or two meso-positions by diphenylphosphine oxide groups have been prepared also by the palladiumcatalyzed reaction of diphenylphosphine or its oxide with the corresponding bromoporphyrins. Complexes were isolated in yields of $60-95 \%{ }^{[26]}$ Attempts to isolate tertiary phosphines using the reduction by $\mathrm{Cl}_{3} \mathrm{SiH}$ or $\mathrm{LiAlH}_{4}$ failed due to extreme air sensitivity of these phosphines.

Arnold and coworkers have also described the coordination properties of porphyrinyl phosphine oxide towards $\mathrm{Mg}(\mathrm{II})$ porphyrins. ${ }^{[27]}$ As an example, the coordination of the $\mathrm{Mg}(\mathrm{II})$ diphenylporphyrin 22 with the free base porphyrinylphosphine oxide $\mathbf{2 1}$ or its Ni complex 23 gave the corresponding diporphyrins 24 and 25 (Scheme 12). These complexes were isolated in excellent yield $(>92$ $\%$ ) and it was shown that $\mathrm{Mg}(\mathrm{II})$ porphyrins have a very high affinity towards phosphine oxides.

The same group has also prepared the first strong binding synthetic analogue 26 of the "special pair" of the photosynthetic reaction center by insertion of $\mathrm{Mg}$ (II) into the free base 21 (Scheme 13). ${ }^{[27]}$

In 2007 Matano and coworkers reported the synthesis of two kinds of meso-phosphorylporphyrins by copper-catalyzed C-P coupling of meso-iodoporphyrinatozinc 27 with di- $n$-butylphosphite under Buchwald's conditions (Scheme 14). ${ }^{[28]}$ meso-(Di- $n$-butoxyphosphoryl) porphyrinatozinc 28

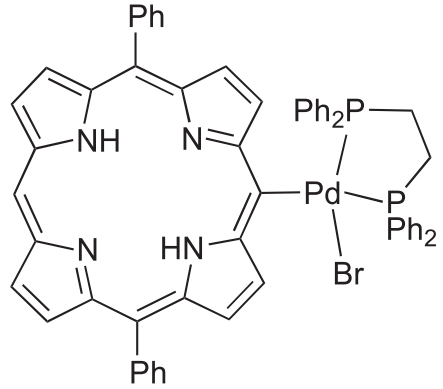

20<smiles></smiles>

21

Scheme 11.

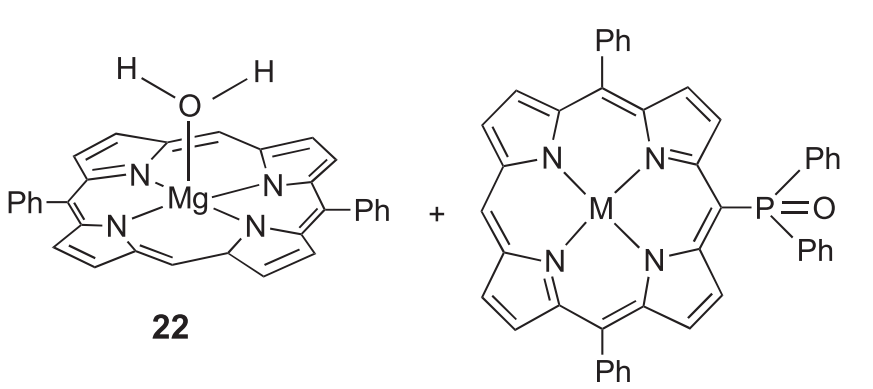

$21: M=2 \mathrm{H}$

$23: \mathrm{M}=\mathrm{Ni}$

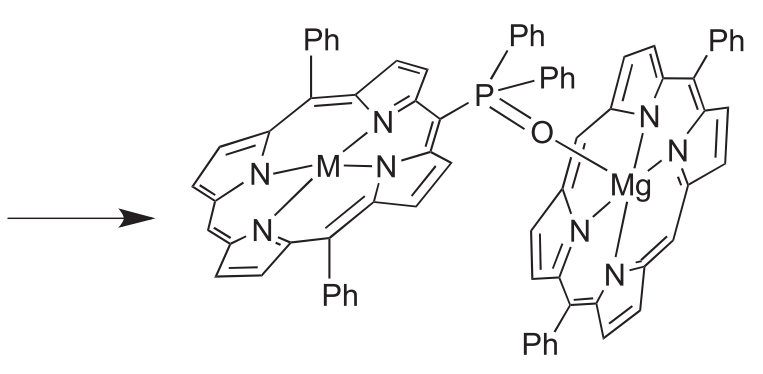

$24: M=2 \mathrm{H}$

$25: \mathrm{M}=\mathrm{Ni}$

Scheme 12.<smiles></smiles>

21

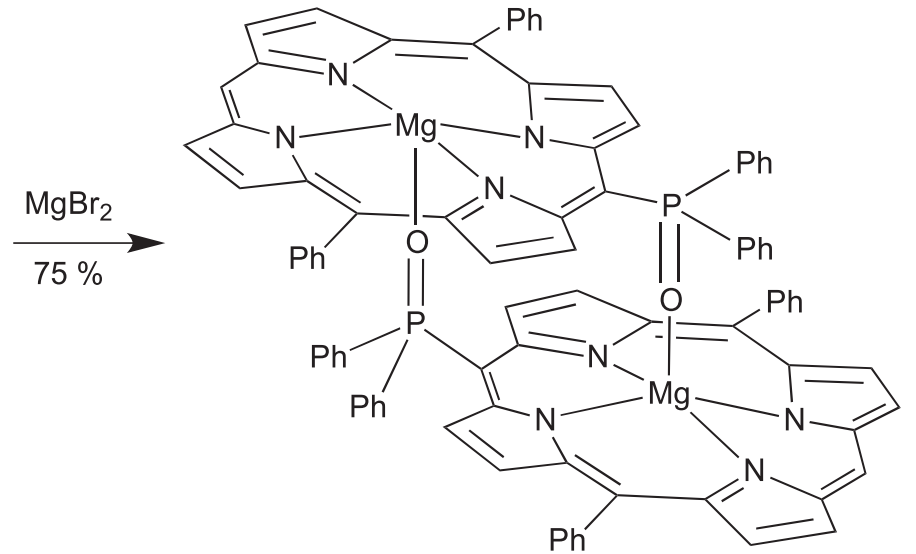


<smiles>CC(C)(C)c1cc(C#[Al])cc(C(C)(C)C)c1</smiles>

27

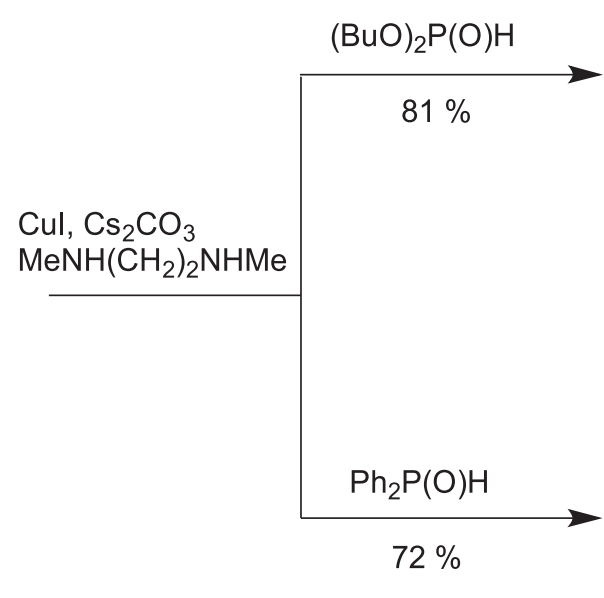

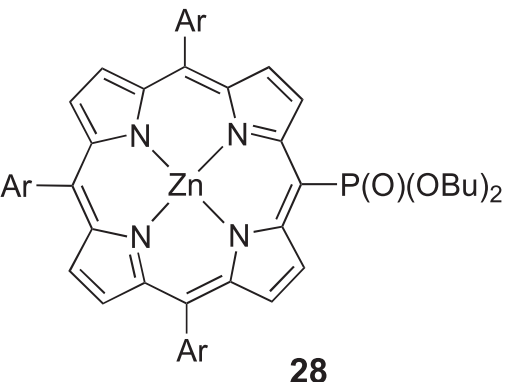

28

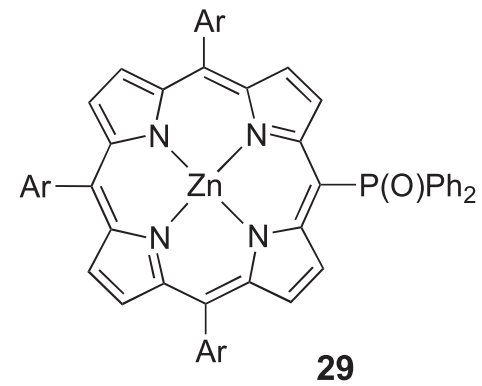

\section{Scheme 14.}

was obtained in $81 \%$ yield using $20 \mathrm{~mol} \% \mathrm{CuI}, 1,2$-dimethylethylenediamine as a ligand and $\mathrm{Cs}_{2} \mathrm{CO}_{3}$ as a base. Using diphenylphosphine oxide instead of di- $n$-butylphosphite gave the corresponding meso-diphenylphosphorylporphyrinatozinc 29 in $72 \%$ yield.

In the course to prepare porphyrin dimers linked by peripherally fused phosphametallocycles in palladium and platinum series, the same group used the Pd-catalyzed C-P cross-coupling reaction of meso-iodoporphyrins $(27,30)$ with diphenylphosphine in $\mathrm{MeCN} / \mathrm{THF}$ to produce the corresponding meso-(phosphinyl)porphyrins (31a,b) (Scheme 15). ${ }^{[29]}$ This air sensitive derivative was readily oxidized in air to meso-phosphoryl porphyrin (32a). Consequently, the crude reaction mixture of $\mathbf{3 1 a , b}$ was reacted with elemental sulfur to afford the air stable meso-(thiophosphoryl)porphyrin $(33 a, b)$ in $87-92 \%$ yields. The quantitative desulfurization of these derivatives were obtained by treatment with excess of $\mathrm{P}\left(\mathrm{NMe}_{2}\right)_{3}$ in refluxing toluene.

Palladium-catalyzed phosphorylations both at the meso position of the porphyrin ring and at the $p$-bromophenyl substituents were described by Enakieva et al. ${ }^{[30-32]}$ The $\mathrm{A}_{4}$ and $\mathrm{A}_{2} \mathrm{~B}_{2}$ porphyrin types were obtained, the $\mathrm{A}_{2} \mathrm{~B}_{2}$ type being isolated in modest to good yields depending of the reaction conditions (Scheme 16).

First, these reactions performed with diethylphosphite, $\mathrm{Pd}(\mathrm{OAc})_{2} / \mathrm{PPh}_{3}$ and $\mathrm{Et}_{3} \mathrm{~N}$ in ethanol show that the nature of the reaction solvent is a key parameter. Indeed, a good yield of the 5,15-bis-(diethoxyphosphoryl)-10,20diphenyl-porphyrinatozinc 37 (51\%) was described by Kadish et al. when ethanol was used as a solvent and dibromide 34 as the precursor (Scheme 17). ${ }^{[31]}$ Moreover, the phosphorylation reaction of the $\mathrm{Zn}$ porphyrin gave

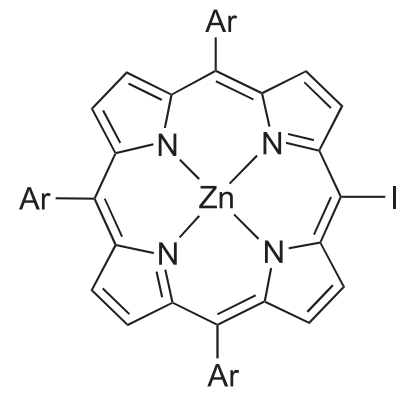

27: $\mathrm{Ar}=3,5-(t-\mathrm{Bu})_{2} \mathrm{C}_{6} \mathrm{H}_{3}$ 30: $\mathrm{Ar}=2,4,6-\mathrm{Me}_{3} \mathrm{C}_{6} \mathrm{H}_{2}$

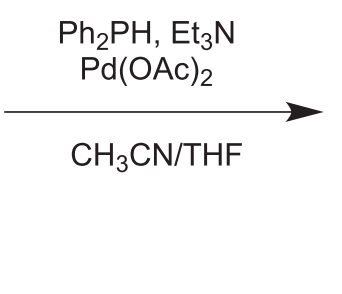

$(E=O) 32 a$

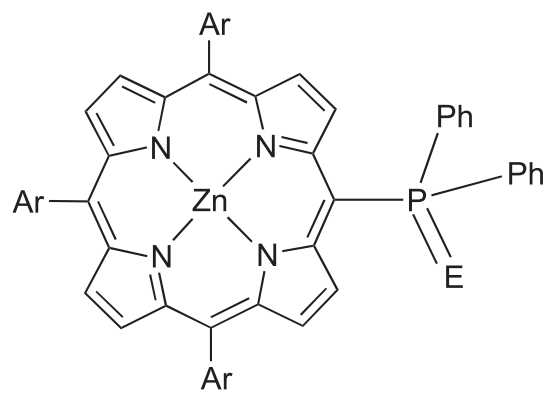

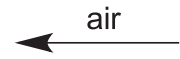

31a,b ( $E=$ lone pair)

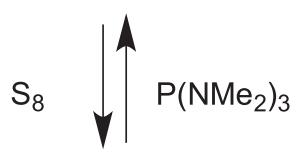

33a,b $(E=S)$

(a : precursor 27)

(b : precursor 30 ) 
R. Guilard et al.

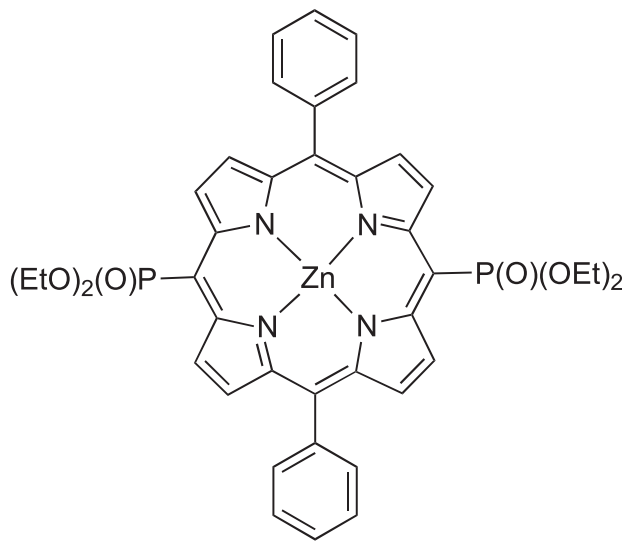<smiles>CCOC(=O)c1c2nc(c(-c3ccccc3)c3ccc([nH]3)c(PCC)c3ccc([nH]3)c(-c3ccccc3)c3nc1C=C3)C=C2</smiles>

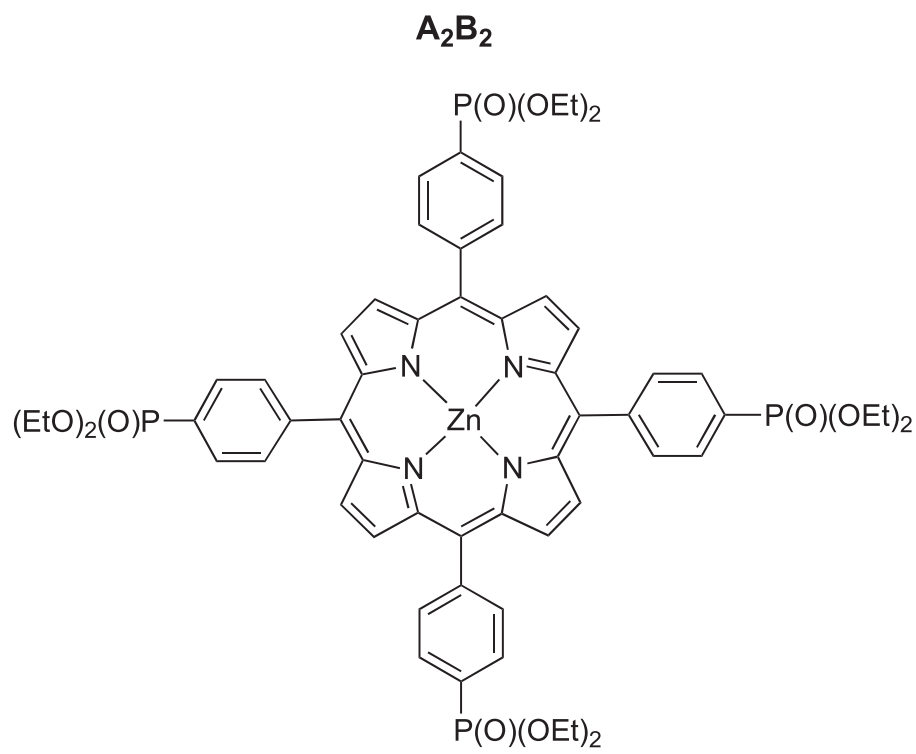

$\mathrm{A}_{4}$

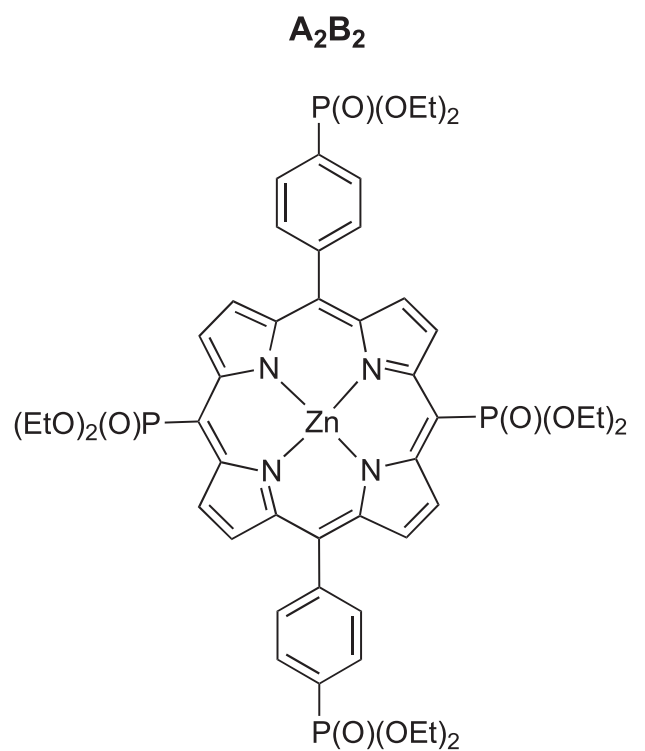

$A_{2} B_{2}$

Scheme 16.

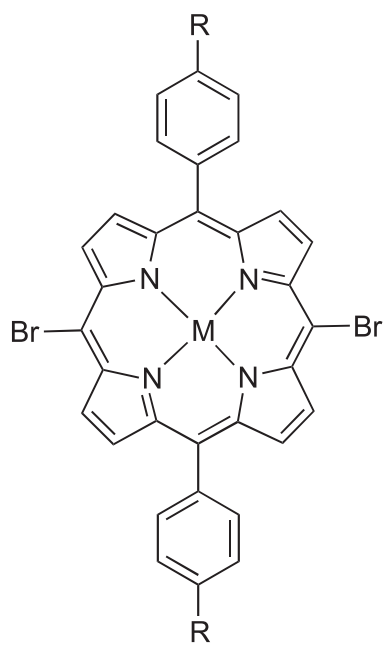

$34: M=Z n, R=H$

$35: \mathrm{M}=\mathrm{Zn}, \mathrm{R}=\mathrm{CH}_{3}$

$36: M=2 H, R=H$

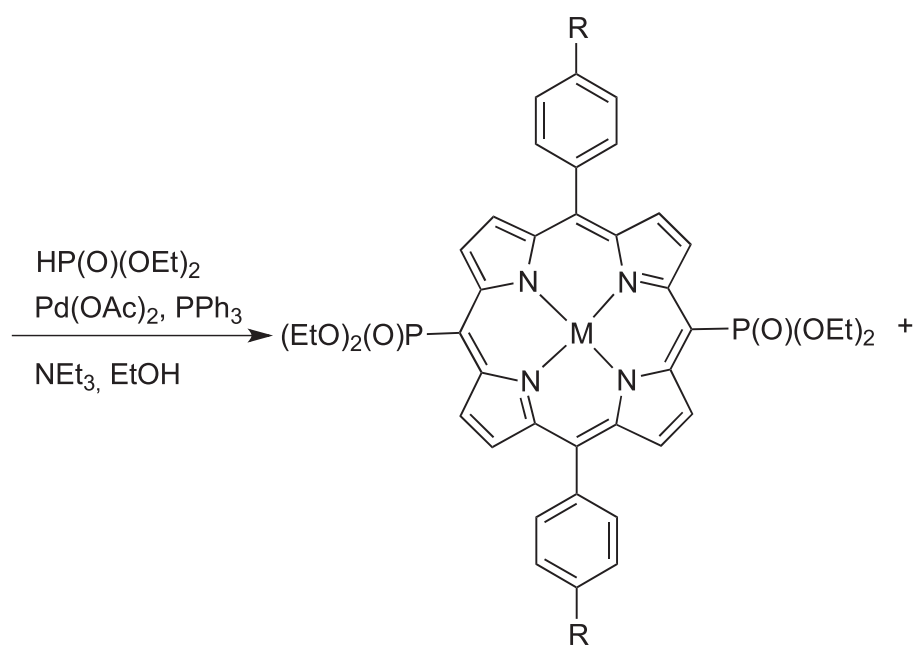

$37: M=Z n, R=H$

$38: \mathrm{M}=\mathrm{Zn}, \mathrm{R}=\mathrm{CH}_{3}$

$39: M=2 H, R=H$

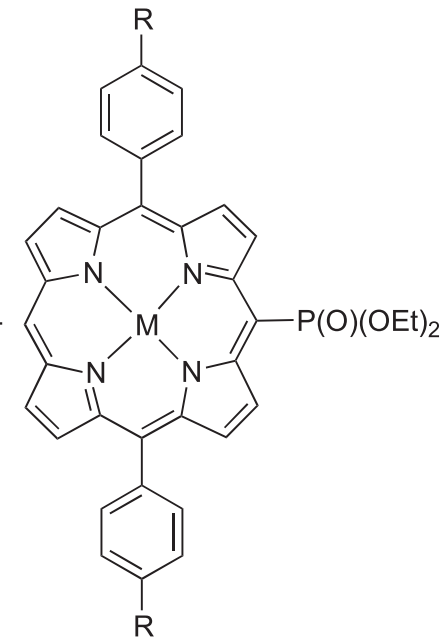

$40: M=Z n, R=H$

$41: \mathrm{M}=\mathrm{Zn}, \mathrm{R}=\mathrm{CH}_{3}$

$42: M=2 H, R=H$

Scheme 17. 


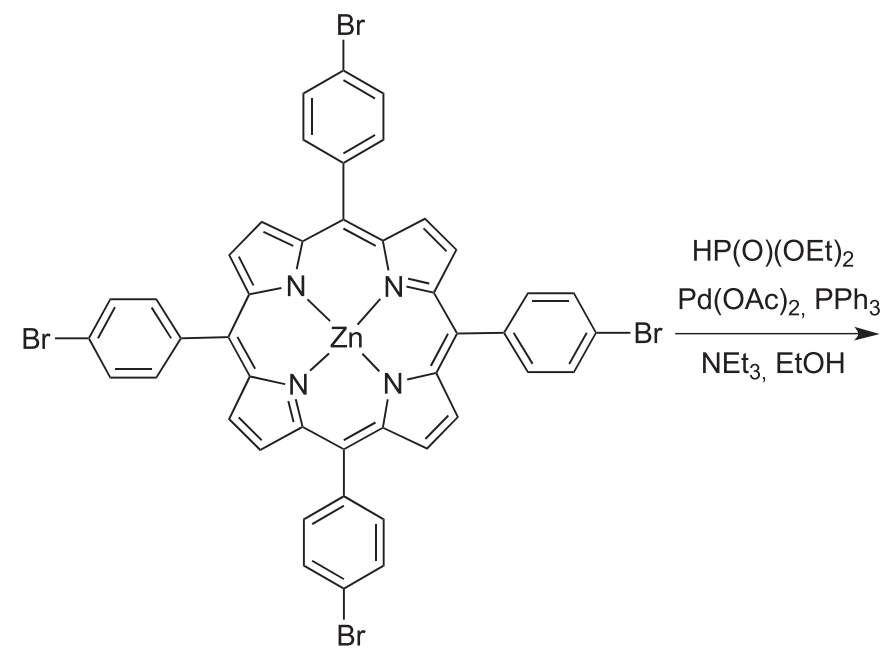

43

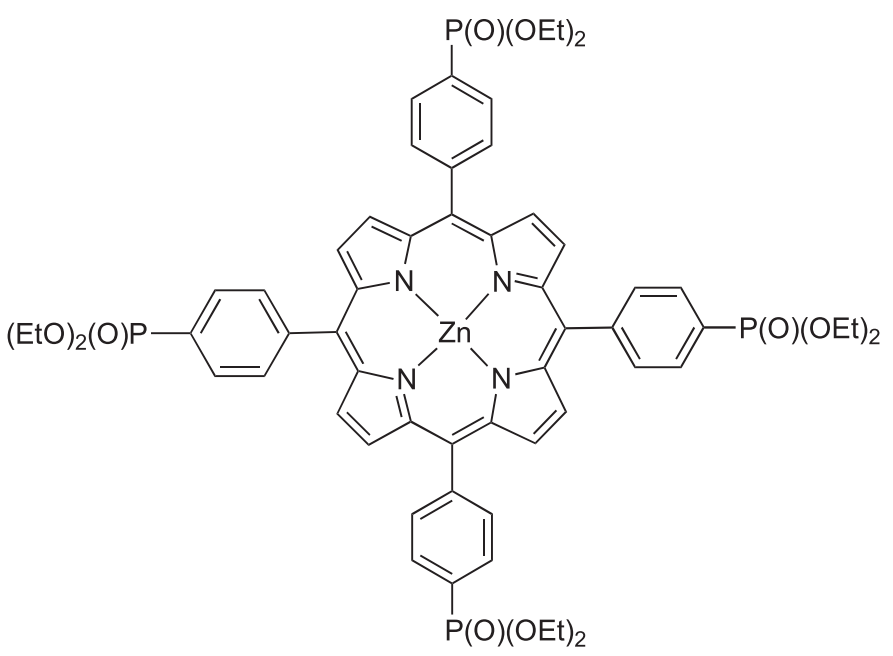

44

Scheme 18.

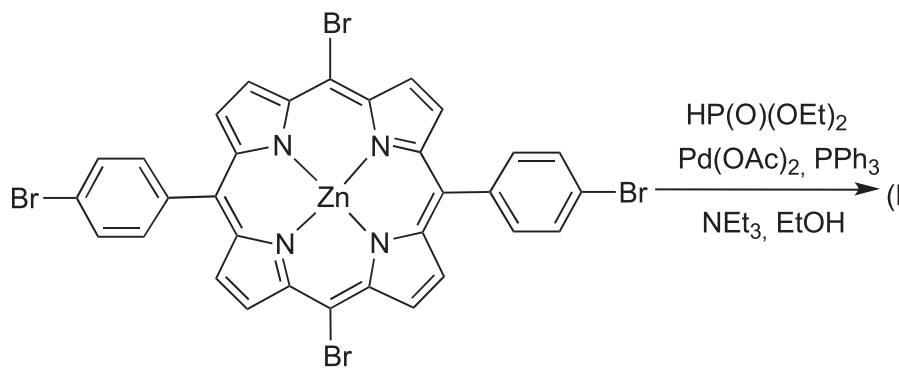

45

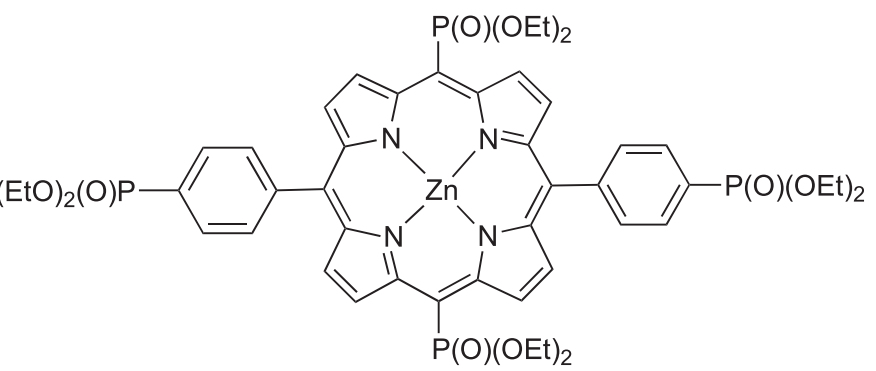

46

\section{Scheme 19.}

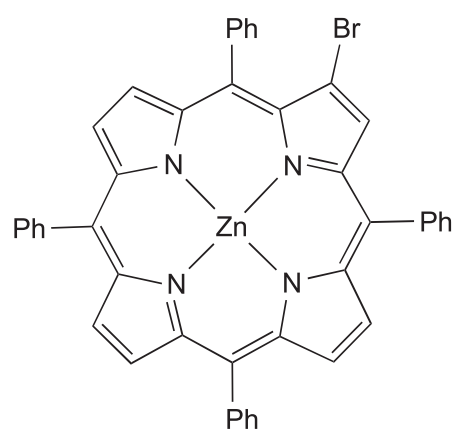

47

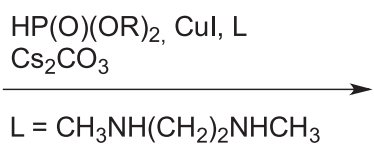

$\mathrm{L}=\mathrm{CH}_{3} \mathrm{NH}\left(\mathrm{CH}_{2}\right)_{2} \mathrm{NHCH}_{3}$<smiles></smiles>

$\mathrm{R}=\mathrm{Et}, n-\mathrm{Bu}, i-\mathrm{Pr}$

48a-c

Scheme 20.

higher yield of the target product compared to the reaction involving the corresponding free base $\mathbf{3 6}$ as a precursor. A hydrodebromination reaction was also observed under these conditions giving the porphyrins without phosphoryl groups and the monophosphoryl derivatives (40-42).

It is remarkable to note that the above conditions have been used to prepare the meso-tetra-(4-diethoxyphosphoryl) phenylporphyrins where the diethoxyphosphoryl substituents are attached to the meso-position of the porphyrin macrocycle via an aryl spacer. The four C-P bonds can be formed in a onepot procedure from $\mathbf{4 3}$ to give a tetraphosphoryl substituted $\mathrm{A}_{4}$ type porphyrin 44 (Scheme 18). ${ }^{[30]}$ The yield observed for the preparation of this complex was much higher (68\%) than the yield observed for the phosphorylation of the free base in toluene. ${ }^{[33]}$

The $\mathrm{A}_{2} \mathrm{~B}_{2}$ type phosphorylated porphyrin 46 was obtained using the same conditions by phosphorylation of the tetrabrominated $\mathbf{4 5}$ precursor where two bromine atoms are directly linked to the macrocycle ring and another two bromine atoms through an aryl spacer (Scheme 19). ${ }^{[31]}$

The first synthesis of zinc $\beta$-phosphorylporphyrins was reported by Vinogradova et al. ${ }^{[34]} \beta$-Dialkoxyphosphoryl tetraphenylporphyrins and their $\mathrm{Zn}$ complexes were synthesized using $\mathrm{Cu}$ and $\mathrm{Pd}$ catalysts. 
<smiles>COC(=O)OCc1ccccc1</smiles>

49

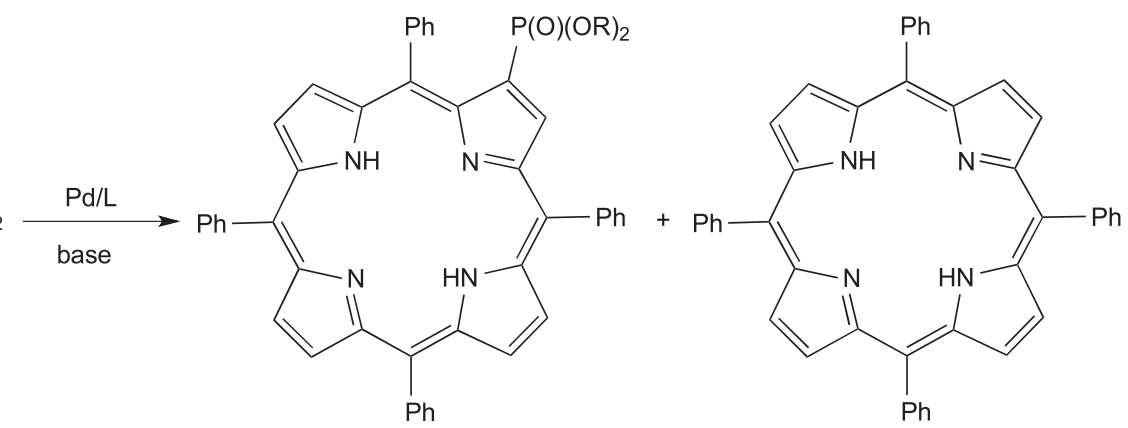

$50 a, b$

$\mathrm{R}: \mathrm{a}=\mathrm{Et}, \mathrm{b}=n-\mathrm{Bu}$

Scheme 21.<smiles>BrC1=C(Br)C2=C(c3ccccc3)c3ccc([nH]3)C(c3ccccc3)=c3c(Br)c(Br)c4c(Br)c3C(=C(c3ccccc3)C1=N2)N=4</smiles>

51

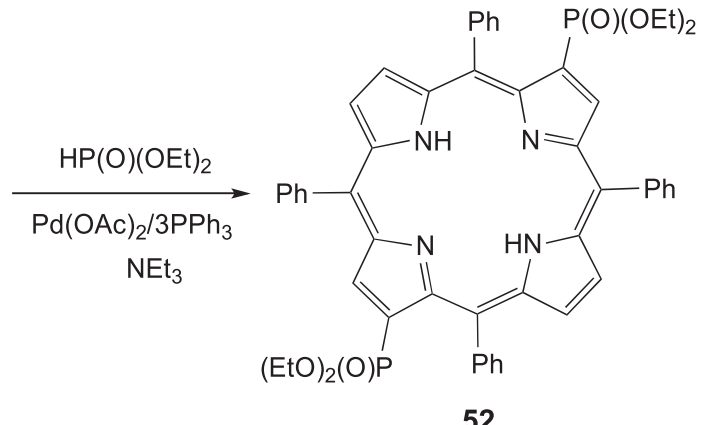

52

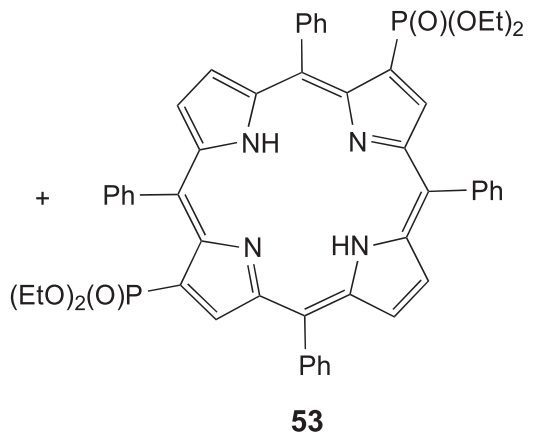

53

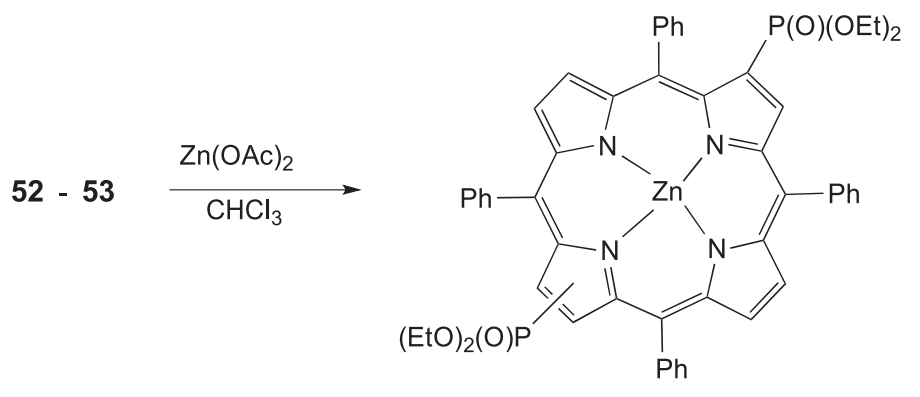

$54-55$

\section{Scheme 22.}

The reaction of zinc bromoporphyrinate 47 with dialkyl phosphite was studied using the Buchwald's catalytic system (Scheme 20). ${ }^{[34]}$ The target products 48 were only obtained in high yield $(>85 \%)$ when the precursor was reacted with phosphites using an excess of copper iodide (3 equiv.) and diamine (21 equiv.). In fact the key parameter of the reaction is the presence of the diamine because the aimed product is not formed in the absence of this ligand.

The reactivity of the $\mathrm{H}_{2} \mathrm{TPPBr} 49$ and $\mathrm{ZnTPPBr} 47$ in the presence of palladium catalysts was different compared to the meso-dibromoporphyrins. The best yield have been obtained using $\left[\mathrm{Pd}(\mathrm{OAc})_{2} / 3 \mathrm{PPh}_{3}\right]$ (1 equiv.) and $\mathrm{NEt}_{3}$ when toluene was used as a solvent instead of ethanol. This can be due to the low solubility of $\mathrm{H}_{2} \mathrm{TPPBr}$ in ethanol which was the best solvent for meso-dibromoporphyrins. The product 50a was isolated in $87 \%$ yield, $\mathrm{H}_{2}$ TPP being the only side product (Scheme 21). ${ }^{[34]}$ Surprisingly the reactivity of $\mathrm{H}_{2}$ TPPBr is similar to that of $\mathrm{ZnTPPBr}$ and full conversion of the starting bromide using the optimal conditions is obtained.

Catalytic conditions were also studied to perform the coupling of 49 with diethylphosphite. Changing the system from $\left[\mathrm{Pd}(\mathrm{OAc})_{2} / 3 \mathrm{PPh}_{3}\right]$ to $\mathrm{Pd}\left(\mathrm{PPh}_{3}\right)_{4}$ led to complex 50a in $72 \%$ yield using $25 \mathrm{~mol} \%$ of catalyst. Further decrease in the catalyst loading to $15 \mathrm{~mol} \%$ led to an incomplete conversion of 49 and a significant increase of by-product ( $\left.\mathrm{H}_{2} \mathrm{TPP}\right)$.

These Pd-catalyzed reactions further applied to the 2,3,12,13-tetrabromo-5,10,15,20-tetraphenylporphyrin $\left(\mathrm{H}_{2} \mathrm{TPPBr}_{4}\right) 51$ gave the starting material and a complex mixture of products (Scheme 22). ${ }^{[34]}$ The MALDI-TOF and NMR spectral analysis of the mixture led to assume that the phosphorylation reaction takes place only after the reduction of one of the neighbouring bromine to form a mono- $\beta$-diethoxyphosphoryl substituted pyrrole moiety. Finally, it was shown that a mixture of toluene and ethanol was needed to increase the solubility of the porphyrin, to facilitate the reduction and the consecutive phosphorylation of the resulting bromoporphyrins. By using a specific rate of solvents (ethanol/toluene 2:3), the two bis(phosphoryl) porphyrins $\mathbf{5 2}$ and $\mathbf{5 3}$ were obtained in equal amounts with a global yield of $81 \%$. The separation of regioisomers by column chromatography is difficult but the corresponding zinc complexes obtained by metallation of the free bases mixture were separated by chromatography. 


\section{Conclusions}

This review focused on the synthesis of phosphoryl substituted porphyrins demonstrate clearly that the transition metal-mediated or catalyzed C-P bond-forming reactions can be successfully applied to the synthesis of essential precursors possessing phosphonate moieties as anchoring groups. Indeed for a long time, most of the phosphonate porphyrins used as structural blocks in material chemistry, for mimicking biological processes or building blocks for self organization of highly ordered assemblies were porphyrins substituted by phosphonate moieties not directly linked to the meso- or $\beta$-pyrrolic position of the macrocycle. The transition metal-catalyzed C-P cross coupling reaction of meso- or $\beta$-halogenoporphyrins led to new series of $\mathrm{A}_{4}, \mathrm{~A}_{3} \mathrm{~B}, \mathrm{~A}_{2} \mathrm{~B}_{2}$ types porphyrins which exhibit a priori new and novel chemical and physical properties. It was already shown that the self assembling of these phosphoryl $\mathrm{Zn}$ (II) and $\mathrm{Cu}(\mathrm{II})$ porphyrins should be observed in solid state and in solution. ${ }^{[30-32,34,35]}$ This self assembling leads to $1 \mathrm{D}$ and $2 \mathrm{D}$ networks. At last but not least, the new $\mathrm{A}_{3} \mathrm{~B}$ type phosphorylated porphyrins should be very good precursors in order to construct efficient DSSCs and to develop photocatalysts. It is very well known that the efficiency of the electron transfer step at a dye semi-conductor is dependent on how the chromophore is attached to the surface.

Acknowledgements. This work was performed in the frame of the French-Russian Associated Laboratory "LAMREM" supported by the CNRS and the Russian Academy of Sciences, Russian Foundation for Basic Research (grant \#12-03-93110).

\section{References}

1. Chambron J.-C., Heitz V., Sauvage J.-P. In: The Porphyrin Handbook (Kadish K.M., Smith K.M., Guilard R., Eds.), Academic Press: San Diego, 2000, Vol. 6, 1-42.

2. Chou J.-H., Kosal M.E., Nalwa H.S., Rakow N.A., Suslick K.S. In: The Porphyrin Handbook (Kadish K.M., Smith K.M., Guilard R., Eds.), Academic Press: San Diego, 2000, Vol. 6, 43-131.

3. Harvey P.D. In: The Porphyrin Handbook (Kadish K.M., Smith K.M., Guilard R., Eds.), Academic Press: San Diego, 2003, Vol. 18, 63-250.

4. Atefi F., Arnold D.P. J. Porphyrins Phthalocyanines 2008, 12, 801-831.

5. Beletskaya I.P., Tyurin V.S., Tsivadze A.Y., Guilard R., Stern C. Chem. Rev. 2009, 109, 1659-1713.

6. Campbell W.M., Burrell A.K., Officer D.L., Jolley K.W. Coord. Chem. Rev. 2004, 248, 1363-1379.

7. Hagfeldt A., Boschloo G., Sun L., Kloo L., Pettersson H. Chem. Rev. 2010, 110, 6595-6663.

8. Walter M.G., Rudine A.B., Wamser C.C. J. Porphyrins Phthalocyanines 2010, 14, 759-792.

9. Nazeeruddin M.K., Baranoff E., Gratzel M. Solar Energy 2011, $85,1172-1178$.
10. Li L.-L., Diau E.W.-G. Chem. Soc. Rev. 2013, 42, 291-304.

11. Evans B., Smith K.M. Tetrahedron Lett. 1977, 18, 3079-3082.

12. Smith K.M., Barnett G.H., Evans B., Martynenko Z. J. Am. Chem. Soc. 1979, 101, 5953-5961.

13. Padilla A.G., Wu S.-M., Shine H.J. J. Chem. Soc., Chem. Commun. 1976, 236-237.

14. Shine H.J., Padilla A.G., Wu S.-M. J. Org. Chem. 1979, 44, 4069-4075.

15. Giraudeau A., Elkahef L. Can. J. Chem. 1991, 69, 1161-1165.

16. Malek A., Latosgrazynski L., Bartczak T.J., Zadlo A. Inorg. Chem. 1991, 30, 3222-3230.

17. Ruhlmann L., Giraudeau A. Chem. Commun. 1996, 2007-2008.

18. Ruhlmann L., Giraudeau A. Eur. J. Inorg. Chem. 2001, 659-668.

19. Ruhlmann L., Gross M., Giraudeau A. Chem. Eur. J. 2003, 9, 5085-5096.

20. Loewe R.S., Ambroise A., Muthukumaran K., Padmaja K., Lysenko A.B., Mathur G., Li Q.L., Bocian D.F., Misra V., Lindsey J.S. J. Org. Chem. 2004, 69, 1453-1460.

21. Muthukumaran K., Loewe R.S., Ambroise A., Tamaru S.I., Li Q.L., Mathur G., Bocian D.F., Misra V., Lindsey J.S. J. Org. Chem. 2004, 69, 1444-1452.

22. Saito M., Nishibayashi Y., Uemura S. Organometallics 2004, 23, 4012-4017.

23. Deniaud D., Schollhorn B., Mansuy D., Rouxel J., Battioni P., Bujoli B. Chem. Mater. 1995, 7, 995-1000.

24. Odobel F., Blart E., Lagree M., Villieras M., Boujtita H., El Murr N., Caramori S., Bignozzi C.A. J. Mater. Chem. 2003, 13, 502-510.

25. Atefi F., Locos O.B., Senge M.O., Arnold D.P. J. Porphyrins Phthalocyanines 2006, 10, 176-185.

26. Atefi F., McMurtrie J.C., Turner P., Duriska M., Arnold D.P. Inorg. Chem. 2006, 45, 6479-6489.

27. Atefi F., McMurtrie J.C., Arnold D.P. Dalton Trans. 2007, 2163-2170.

28. Matano Y., Matsumoto K., Terasaka Y., Hotta H., Araki Y., Ito O., Shiro M., Sasamori T., Tokitoh N., Imahori H. Chem. Eur. J. 2007, 13, 891-901.

29. Matano Y., Matsumoto K., Nakao Y., Uno H., Sakaki S., Imahori H. J. Am. Chem. Soc. 2008, 130, 4588-4589.

30. Enakieva Y.Y., Bessmertnykh A.G., Gorbunova Y.G., Stern C., Rousselin Y., Tsivadze A.Y., Guilard R. Org. Lett. 2009, 11, 3842-3845.

31. Kadish K.M., Chen P., Enakieva Y.Y., Nefedov S.E., Gorbunova Y.G., Tsivadze A.Y., Bessmertnykh-Lemeune A., Stern C., Guilard R. J. Electroanal. Chem. 2011, 656, 61-71.

32. Sinelshchikova A.A., Nefedov S.E., Enakieva Y.Y., Gorbunova Y.G., Tsivadze A.Y., Kadish K.M., Chen P., BessmertnykhLemeune A., Stern C., Guilard R. Inorg. Chem. 2013, 52, 9991008.

33. Kubat P., Lang K., Anzenbacher P. Biochim. Biophys. Acta 2004, 1670, 40-48.

34. Vinogradova E.V., Enakieva Y.Y., Nefedov S.E., Birin K.P., Tsivadze A.Y., Gorbunova Y.G., Lemeune Bessmertnykh A., Stern C., Guilard R. Chem. Eur. J. 2012, 15092-15104.

35. Fang Y.Y., Kadish K.M., Chen P., Gorbunova Y., Enakieva Y., Tsivadze A., Bessmertnykh-Lemeune A., Guilard R. J. Porphyrins Phthalocyanines 2013, 17, 1035-1045. 